\title{
Optimizing the Saccharification of Pretreated Wood Biomass using Crude Enzyme from Acanthophysium Sp. KMF001
}

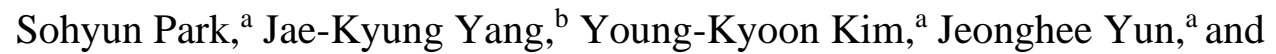
Yeong-suk Kim ${ }^{\text {a,* }}$

This study was conducted on crude enzyme from the novel strain Acanthophysium sp. KMF001 using a mediator (surfactant). The surfactant was applied to the steam-exploded pretreated domestic wood biomass, and response surface methodology (RSM) was conducted to determine the optimum conditions for saccharification using the optimum substrate concentration, enzyme concentration, and surfactant concentration. Steam-explosion of Korean oak $\left(25 \mathrm{kgf} / \mathrm{cm}^{2}\right)$ for $7 \mathrm{~min}$ showed a maximum-predicted saccharification of approximately $99.9 \%$ at $7.0 \%$ substrate concentration, 37.5 FPU (filter paper units) enzyme concentration, and $475.8 \mathrm{mg} / \mathrm{g}$-glucan surfactant (polysorbate 80 ) concentration. Steam-explosion of red pine $\left(25 \mathrm{kgf} / \mathrm{cm}^{2}\right)$ for $7 \mathrm{~min}$ revealed a maximum prediction saccharification rate of approximately $58.7 \%$ at $6.5 \%$ substrate concentration, $36.3 \mathrm{FPU}$ enzyme concentration, and 330.3 $\mathrm{mg} / \mathrm{g}$-glucan surfactant (polysorbate 80 ) concentration. The extents of saccharification of Korean oak (99.9\%) and pine (58.7\%) demonstrated the high applicability of the crude enzyme from Acanthophysium sp. KMF001.

Keywords: Cellulase, Optimization, Saccharification, stream-explosion, Acanthophysium sp. KMF001

Contact information: a: Department of Forest Products and Biotechnology, Kookmin University, Seoul 02707, Republic of Korea; $b$ : Division of Environmental Forest Science and Institute of Agriculture \& Life Science, Gyeongsang National University, Jinju 52828, Republic of Korea; * Corresponding author: yskim@kookmin.ac.kr

\section{INTRODUCTION}

As a second-generation bioenergy resource, wood includes hydrophobic lignin (composed of many aromatic compounds) and carbohydrates (cellulose and hemicellulose). Cellulose hydrolysis is known to be a difficult process because lignin is present along with cellulose (Sun and Cheng 2002; Salvi et al. 2010; Kim 2011; Singh et al. 2015). Therefore, there is a need to determine the optimum pretreatment and saccharification methods (Sun and Cheng 2002; Ballesteros et al. 2006; Datar et al. 2007; Singh et al. 2015).

Hydrolysis, which entails the addition of one molecule of water per glycosidic linkage in cellulose, is responsible for the saccharification of wood biomass. Enzymatic saccharification means that this hydrolysis is catalyzed by cellulase, which is derived from wood-destroying fungi, whereas chemical saccharification uses catalysts such as acids or alkali (Kim 2011; Singh et al. 2015).

Enzymatic saccharification avoids environmental contamination or metal corrosion because the hydrolysis using cellulase protein occurs under mild conditions (Valchev et al. 2009; Kim 2011; Singh et al. 2015). Reducing energy cost is advantageous because the use of a large number of chemicals, recovery, and naturalization processes of chemicals is not required (Valchev et al. 2009; Kim 2011; Singh et al. 2015). However, cellulase is not substrate-specific and many enzymes are subject to nonproductive 
adsorption, and denaturation of enzyme can adversely affect the pretreatment process (Eriksson et al. 2002; Börjesson et al. 2007a; Kim 2011). Inhibitory factors of saccharification include the composition and lignin contents of wood biomass-lignin droplets, crystallinity, surface area, porosity volume, and activity and denaturation of enzymes (Sewalt et al. 1997; Eriksson et al. 2002; Zhang and Lynd 2004: Selig et al. 2007; Yoshida et al. 2008). Wood biomass has a relatively high lignin content in comparison to herbaceous plants; thus, lignin removal is an important factor of wood biomass saccharification due to the inhibitory activity of lignin (Sewalt et al. 1997; Mooney et al. 1998; Selig et al. 2007; Kim 2011). For the saccharification of wood biomass, pretreatment is performed to remove inhibitors and improve saccharification rate. Problems as a result of pretreatment using acid and alkali, such as the generation of inhibitory factors on saccharification/fermentation and high cost have been reported (Ballesteros et al. 2006; Datar et al. 2007; Valchev et al. 2009; Singh et al. 2015). Steam-explosion pretreatment generally improves enzymatic saccharification in subsequent processes, as hemicellulose in the pretreatment process is depolymerized, becoming water-soluble, exposing the micropores within the biomass; the consequence is an increased area the surface where cellulose can bind to the enzyme (Sewalt et al. 1997; Selig et al. 2007; Biswas et al. 2011).

Many researchers have used mediators (surfactants) to prevent the inhibition of enzyme saccharification by lignin droplets or lignin remnants after pretreatment (Castanon and Wilke 1981; Ballesteros et al. 1998; Kaar and Holtzapple 1998; Alkasrawi et al. 2003; Yang and Wyman 2006; Börjesson et al. 2007a; Kristensen et al. 2007; Pandey and Negi 2015). Many types of mediators, such as nonionic, amphoteric, cationic, anionic surfactant, and bovine serum albumin (BSA) have been demonstrated. Among these mediators, it was reported that nonionic substances esters of fatty acids such as polysorbate (Tween) and polymers (polyethylene glycol (PEG)) are effective (Castanon and Wilke 1981; Kaar and Holtzapple 1998; Alkasrawi et al. 2003; Börjesson et al. 2007a; Sipos et al. 2010; Pandey and Negi 2015). Mediators have positive effects in preventing enzyme denaturation (Kaar and Holtzapple 1998; Börjesson et al. 2007a), improving the surface characteristics of substance (Eriksson et al. 2002; Börjesson et al. 2007a; Sipos et al. 2010), and binding substances and enzyme (Kaar and Holtzapple, 1998; Börjesson et al. 2007a).

To effectively improve the saccharification performance of wood biomass, a statistical design of experiments is frequently used. Among them, the response surface methodology (RSM) is useful for determining interactions involving various factors, which influence saccharification performance. The optimum conditions of RSM have been successfully used in the pretreatment and optimization of enzymatic saccharification (Sun and Chen 2007; Karunanithy and Muthukumarappan 2011a,b; Sindhu et al. 2007, 2011, 2012, 2013). Karunanithy and Muthukumarappan (2011a) reported that switchgrass pretreated under optimum conditions elicited using RSM showed maximum recovery rates of glucose and xylose at $41.4 \%$ and $62.2 \%$, respectively, and the surface of substance was approximately $50 \%$ higher than the initial value. Karunanithy and Muthukumarappan (2011b) reported high recovery rates of glucose and xylose at $86.6 \%$ and $84.5 \%$, respectively, under optimum conditions elicited from the pretreated prairie cordgrass. Sindhu et al. (2012) reported that the optimum conditions for saccharification of rice straw pretreated using acetone had $11.2 \%$ substrate concentration, 60 FPU (filter paper units) enzyme concentration, $0.05 \%(\mathrm{w} / \mathrm{w})$ surfactant concentration, and $60 \mathrm{~h}$ incubation time. The maximum reducing sugar yield was $0.655 \mathrm{~g} / \mathrm{g}$ under optimum conditions. In a study by Sindhu et al. (2011), a maximum reducing sugar yield of $0.685 \mathrm{~g} / \mathrm{g}$ was generated under optimized saccharification conditions from sugarcane tops pretreated using diluted acid. Sun and Chen (2007) reported that the optimum saccharification conditions elicited by the Box-Behnken design (BBD) were 44 FPU/g enzyme concentration, $48 \mathrm{~h}$ reaction time, and $2 \%(\mathrm{w} / \mathrm{w})$ substrate concentration, resulting in a high hydrolysis yield of $92 \%$ from 
pretreated wheat straw. In a study by Sindhu et al. (2007), rice straw pretreated under optimum saccharification conditions $(11.25 \%$ substrate concentration, 50 FPU enzyme concentration, $0.2 \%(\mathrm{w} / \mathrm{w})$ surfactant concentration, and $60 \mathrm{~h}$ incubation time) elicited using BBD generated a reducing sugar yield of $0.374 \mathrm{~g} / \mathrm{g}$. It was also reported that the hydrolysis efficiency increased 6 times higher than the initial (Sindhu et al. 2013).

In the previous study, optimum conditions to produce high-activity cellulase from the novel Acanthophysium sp. KMF001 strain were determined. However, there was no report containing data for the applicability of saccharification to Korean oak and pine using the crude enzyme produced from Acanthophysium sp. KMF001. Also, saccharification performance for Korean oak and pine biomass pretreated using steam-explosion has not been reported. In this study, an improvement of the saccharification performance using a mediator (surfactant) was performed, and the saccharification suitability test of the crude enzyme from the novel strain of Acanthophysium sp. KMF001 was examined. To improve saccharification performance, optimum saccharification conditions of the crude enzyme from Acanthophysium sp. KMF001 for the Korean wood biomass pretreated by steamexplosion using BBD among the RSM was determined.

\section{EXPERIMENTAL}

\section{Test Strain and Crude Enzyme Production}

The novel strain-Acanthophysium sp. KMF001 (KCTC 18282P) was registered at the Korean Culture Center of Microorganisms in the Korean Research Institute of Bioscience and Biotechnology, and the characteristics of the this strain with high cellulase activity was described in the previous paper (Yoon et al. 2019). For the control, the commercial enzyme by Cellic, CTec2 (Novozyme, Basgsværd, Denmark) was used as the reference I. The test strain served as an inoculum for pre-culture after incubation of 5 to 7 $\mathrm{d}$ on potato dextrose agar medium. In the pre-culture, the test strain was inoculated on potato dextrose broth and was used for the main culture after shaking incubation for 4 to 5 $\mathrm{d}$ at $150 \mathrm{rpm}$ and $30{ }^{\circ} \mathrm{C}$. The main culture was conducted using $4 \mathrm{~L}$ of broth medium, including the nutrient constituents of yeast extract $4.5 \mathrm{~g} / \mathrm{L}$, tryptone $10.5 \mathrm{~g} / \mathrm{L}, \mathrm{KH}_{2} \mathrm{PO}_{4} 5$ $\mathrm{g} / \mathrm{L}, \mathrm{K}_{2} \mathrm{HPO}_{4} 5 \mathrm{~g} / \mathrm{L}, \mathrm{MgSO}_{4} \cdot 7 \mathrm{H}_{2} \mathrm{O} 3 \mathrm{~g} / \mathrm{L}$, cellulose (approximately 20 to $100 \mu \mathrm{m}$, DEAJUNG, Siheung-si, Gyeonggi-do, South Korea) $31.11 \mathrm{~g} / \mathrm{L}$. The detailed information for the optimization of the strain culture conditions was described in the previous study (Kim et al. 2016; Yoon et al. 2019). After the pre-culture, 5\% (v/v) of the solution was inoculated into the main culture broth, it was incubated for $14 \mathrm{~d}$ at $30{ }^{\circ} \mathrm{C}, 150 \mathrm{rpm}$, and aeration $2 \mathrm{LPM}$ (liter per minute) under maintenance at pH 5.94 with $2 \mathrm{M} \mathrm{HCl}$ and $2 \mathrm{M} \mathrm{NaOH}$, after which the crude enzyme was collected.

\section{Filtration and Concentration of the Crude Enzyme}

For filtration and concentration of the crude enzyme, the culture solution following incubation for $14 \mathrm{~d}$ was filtered using a filter paper (Whatman No. 1). The filtered crude enzyme was concentrated to a total volume of $50 \mathrm{~mL}$ using amicon stirred cells (UFSC40001, EMD Millipore Corp., Billerica, MA, USA) equipped with a $10 \mathrm{kDa}$ cut-off polyethersulfone (PES) membrane (PM 10 membrane, Milipore Corp.). The concentrated crude enzyme was washed with $0.1 \mathrm{M}$ sodium citrate buffer at $\mathrm{pH} 4.5$, after which the crude enzyme was used for saccharification.

\section{Test Wood Biomass and Pretreatment}

The test wood biomass used was Korean Mongolian oak (Quercus mongolica) and Korean red pine (Pinus densiflora) pretreated using steam-explosion. The Korean oak and pine were selected as major biomass because of their sufficient supply in Korea. Korean 
oak and pine are the dominant tree species in non-coniferous and coniferous forest, respectively, for the forest area and growing stock (Korea Forest Service 2018). The Korean Mongolian oak and Korean red pine were purchased as wood chips produced from logs exploited in Jinju, Gyeongsangnam-do, Korea. The substrate for comparison was cellulose (20 to $100 \mu \mathrm{m}$, Daejung). As shown in Fig. 1, the steam-explosion pretreatment process was conducted at the customized batch pilot unit (Yurim High Tech, Taegu, Gyeongsangbuk-do, Korea) based on the Masonite technology. Steam-explosion treatment was conducted at a reaction time of $3,5,7$, and 13 min under a pressure of $25 \mathrm{kgf} / \mathrm{cm}^{2}$, and the steam-explosion treated oak and pine were collected at the cyclone, cooled to approximately $40^{\circ} \mathrm{C}$, and then filtered for solid recovery. After filtration, the residue was analyzed for chemical composition and then used as a substrate for saccharification.
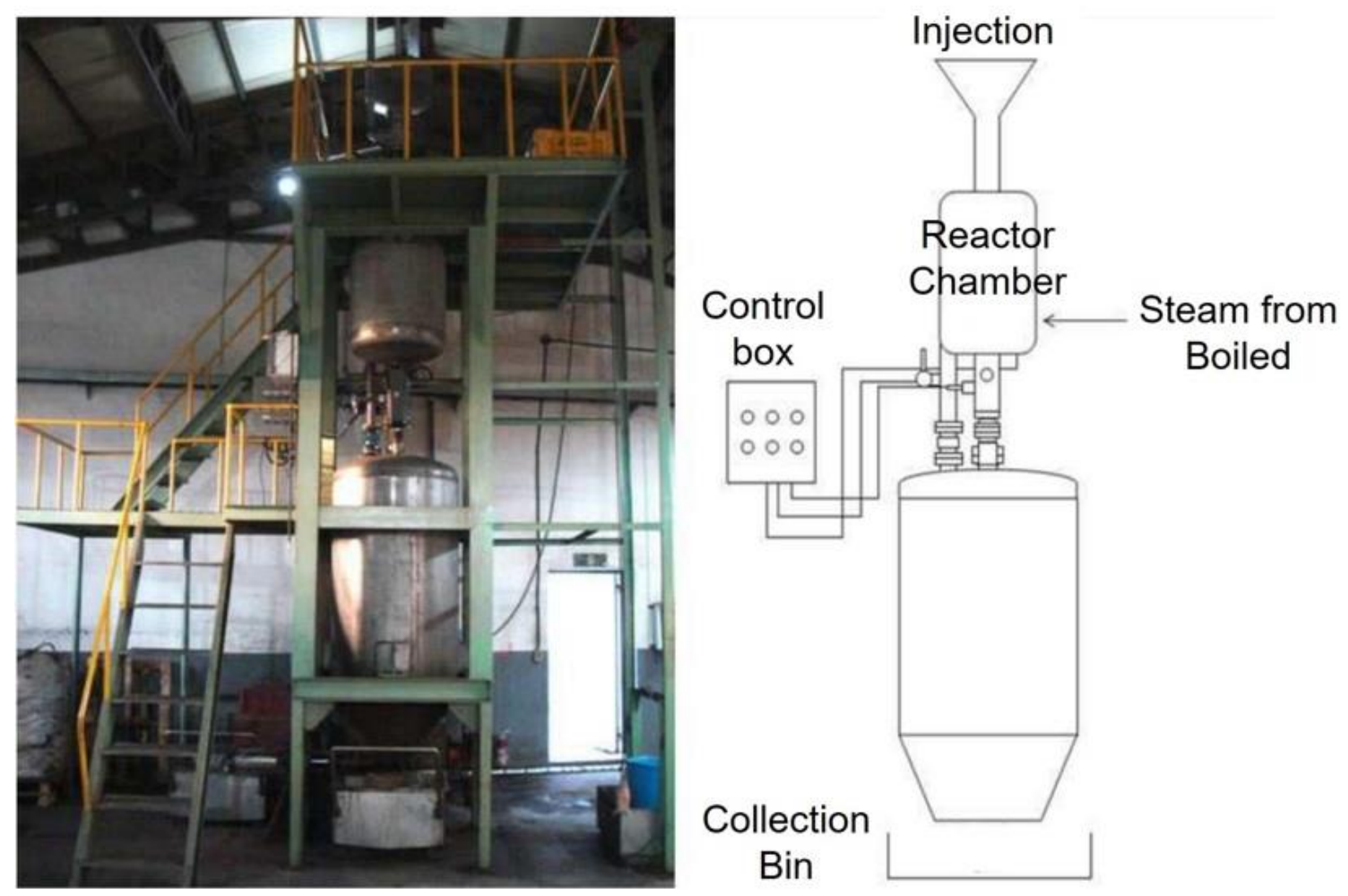

Fig. 1. Steam-explosion machine of Yurim High Tech, Taegu, Gyeongsangbuk-do, Korea

\section{Chemical Composition Analysis of Steam-Explosion Pretreated Wood}

To analyze the chemical composition of the wood biomass, the analysis for glucan, xylan, galactan, arabinan, mannan, lignin, and ash was conducted using the determination of structural carbohydrates and lignin in biomass (NREL/TP-510-42618).

\section{FPU (filter paper unit) Measurement}

For saccharification using crude enzymes of Acanthophysium sp. KMF001, the FPU was measured in accordance with the measurement of cellulase activities (NREL/TP$510-42628$ ). The substrate was a $50 \mathrm{mg}$ of the filter paper strip (Whatman No.1 of $1.0 \mathrm{x}$ $6.0 \mathrm{~cm}$ ), and the cellulase assays was carried out in $100 \mathrm{mM}$ sodium citrate buffer $(\mathrm{pH} 4.5)$. The $50 \mathrm{mg}$ substrate was reacted with the buffer and crude enzyme in a test tube at $50{ }^{\circ} \mathrm{C}$ for $60 \mathrm{~min}$. Next, $3 \mathrm{~mL}$ of DNS (3,5-dinitrosalicylic acid) reagent of was added, and the reaction was stopped in boiling water for $5 \mathrm{~min}$ then cooled at room temperature. The pulping filter paper was centrifuged at 13,500 rpm for $10 \mathrm{~min}$ and left to settle, it was then mixed under the specific ratio with distilled water, and the absorbance of the mixture was measured at $540 \mathrm{~nm}$. 


\section{Optimization Experiment Using Saccharification Enhancer for the saccharification Condition of Wood Biomass}

The BBD was used to optimize the saccharification conditions of wood biomass using a saccharification enhancer to investigate interactions of variables. As important variables influenced enzyme saccharification of wood biomass pretreated using steamexplosion, substrate concentration (\%), enzyme concentration (FPU), and saccharification enhancer concentration (mg/g-glucan) were investigated to determine the optimal conditions. As shown in Table 1, the concentration ranges of each variable were set at three levels of $-1,0$, and +1 for lower, middle, and higher value, respectively: substrate concentration of 3\%,5\%, and 7\%, enzyme concentration of 1020 , and $30 \mathrm{FPU}$, and saccharification enhancer concentration of 100,300 , and $500 \mathrm{mg} / \mathrm{g}$-glucan. Thirty experiments were conducted, and cases of Korean Mongolian oak and Korean red pine applied using the designed experiments with coded units are shown in Table 2 and 3, respectively. The predicted saccharification rates were determined according to the secondorder polynomial model equation,

$G=\beta_{0}+\beta_{1} X_{1}+\beta_{2} X_{2}+\beta_{3} X_{3}+\beta_{11} X_{1}{ }^{2}+\beta_{22} X_{2}{ }^{2}+\beta_{33} X_{3}{ }^{2}+\beta_{12} X_{1} X_{2}+\beta_{13} X_{1} X_{3}+\beta_{23} X_{2} X_{3}$

where $G$ is the predicted saccharification rate; $\beta_{0}$ is the intercept; $\beta_{1}, \beta_{2}$, and $\beta_{3}$ are the linear coefficients; and $\beta_{11}, \beta_{22}$, and $\beta_{33}$ are the interaction coefficients. The statistical analysis of the data was expressed as a three-dimensional response surface graph shape from the multi-dimension equation using ANOVA, to explain the main and interaction effects of independent variables.

Table 1. Levels of Factors for Response Surface Methodological Experiments on Quercus mongolica and Pinus densiflora

\begin{tabular}{|c|c|c|c|c|}
\hline \multicolumn{2}{|c|}{ Factor } & \multicolumn{3}{|c|}{ Levels of Factor } \\
\cline { 3 - 5 } & - & 0 & + \\
\hline 1 & Substrate concentration (\%) & 3 & 6 & 9 \\
\hline 2 & Enzyme concentration (FPU) & 10 & 30 & 50 \\
\hline 3 & Polysorbate 80 (mg/g, glucan) & 100 & 400 & 700 \\
\hline
\end{tabular}

\section{Saccharification of Wood Biomass Pretreated by Steam-Explosion Under Optimal Saccharification Conditions}

The conditions for saccharification of wood biomass pretreated with steamexplosion were applied as follows: In the crude enzyme of Acanthophysium sp. KMF001, saccharification was conducted for $72 \mathrm{~h}$ at a temperature of $35^{\circ} \mathrm{C}, 0.1 \mathrm{M}$ sodium citrate $(\mathrm{pH} 4.5)$, and $250 \mathrm{rpm}$ as the optimal saccharification conditions. In reference I (Cellic,CTec2, Novozyme), which is the control enzyme, saccharification was conducted for $72 \mathrm{~h}$ at a temperature of $50{ }^{\circ} \mathrm{C}, 0.1 \mathrm{M}$ sodium citrate $(\mathrm{pH} \mathrm{5.0})$, and $250 \mathrm{rpm}$. After this process, the enzyme reaction was halted by boiling at $100{ }^{\circ} \mathrm{C}$ for $10 \mathrm{~min}$ and used for sugar analysis.

\section{Sugar Analysis Using DNS}

For the quantification analysis of saccharification products using DNS, sugar analysis was conducted in accordance with the DNS method using 3,5-dinitrosalicylic acid (Alfa Aesar). After the saccharified solution was centrifuged, the supernatant was separated. $30 \mu \mathrm{L}$ sugar solution was mixed with $150 \mu \mathrm{L} \mu \ell$ of $100 \mathrm{mM}$ sodium citrate and $120 \mu \mathrm{L}$ DNS, the mixture was boiled at $100{ }^{\circ} \mathrm{C}$ for $5 \mathrm{~min}$ to stop the reaction and cooled under room temperature. The absorbance of the reducing sugar was measured at $540 \mathrm{~nm}$. 
Table 2. Reducing Sugar (\%, g/g, glucan) for Individual Runs of the BoxBehnken Design on Quercus mongolica

\begin{tabular}{|c|c|c|c|c|}
\hline Run & $\begin{array}{c}\text { Substrate } \\
\text { Concentration (\%) }\end{array}$ & $\begin{array}{c}\text { Enzyme } \\
\text { Concentration } \\
\text { (FPU) }\end{array}$ & $\begin{array}{c}\text { Tween80 } \\
\text { (mg/g, glucan) }\end{array}$ & $\begin{array}{l}\text { Reduced Sugar } \\
\left(\%, g / g, \text { glucan }^{1}\right)\end{array}$ \\
\hline 1 & 0 & 0 & 0 & 92.11 \\
\hline 2 & 0 & + & + & 88.03 \\
\hline 3 & 0 & 0 & 0 & 96.06 \\
\hline 4 & - & + & 0 & 73.22 \\
\hline 5 & 0 & + & - & 99.60 \\
\hline 6 & 0 & 0 & 0 & 89.89 \\
\hline 7 & 0 & 0 & 0 & 91.85 \\
\hline 8 & - & - & 0 & 35.10 \\
\hline 9 & - & 0 & - & 55.14 \\
\hline 10 & 0 & 0 & 0 & 105.09 \\
\hline 11 & - & 0 & + & 82.18 \\
\hline 12 & + & 0 & - & 85.12 \\
\hline 13 & 0 & - & - & 52.51 \\
\hline 14 & - & - & 0 & 31.34 \\
\hline 15 & + & - & 0 & 43.09 \\
\hline 16 & + & + & 0 & 77.80 \\
\hline 17 & 0 & - & + & 54.16 \\
\hline 18 & 0 & + & + & 84.42 \\
\hline 19 & + & 0 & + & 94.47 \\
\hline 20 & 0 & 0 & 0 & 92.15 \\
\hline 21 & + & - & 0 & 67.17 \\
\hline 22 & - & 0 & - & 53.16 \\
\hline 23 & 0 & - & + & 57.02 \\
\hline 24 & + & + & 0 & 95.11 \\
\hline 25 & 0 & - & - & 50.10 \\
\hline 26 & 0 & + & - & 73.57 \\
\hline 27 & + & 0 & + & 84.25 \\
\hline 28 & - & + & - & 58.42 \\
\hline 29 & - & 0 & + & 76.16 \\
\hline 30 & + & 0 & - & 84.90 \\
\hline
\end{tabular}

1) Ratio of the amount of glucose released after enzymatic hydrolysis during saccharification to the total amount of glucose in the initial substrate

\section{RESULTS AND DISCUSSION}

\section{Chemical Composition of Wood Biomass Pretreated Using Steam- Explosion}

The results of the chemical composition analysis of the wood biomass pretreated using steam-explosion are shown in Table 3. As shown, the proportional contents (\%) and actual contents (g) based on the oven dry weight (O.D.W.) were expressed. In Korean Mongolian oak pretreated using steam-explosion, the glucan contents by the treatment time were $37.73 \%(0.109 \mathrm{~g}), 40.63 \%$ (0.112 g), $42.71 \%(0.114 \mathrm{~g})$, and $47.3 \%(0.138 \mathrm{~g})$ for 3,5 , 7 , and $13 \mathrm{~min}$, respectively, and the glucan contents increased for longer treatment time. In Korean red pine pretreated using steam-explosion, the glucan contents by the treatment time were $30.88 \%(0.90 \mathrm{~g}), 32.93 \%(0.093 \mathrm{~g})$, and $34.71 \%(0.101 \mathrm{~g})$ for 3, 7, and $13 \mathrm{~min}$, respectively, and the glucan contents increased for longer treatment time. These results showed a similar tendency to the references related to the steam-explosions (Ballesteros et al. 2006; Ruiz et al. 2008). 
Table 3. Chemical Composition (\%) and Concentration of Polymeric Sugars (g) of Pretreated Wood Biomass under Different Conditions

\begin{tabular}{|c|c|c|c|c|c|c|c|c|c|}
\hline \multirow{2}{*}{$\begin{array}{c}\text { Pre- } \\
\text { Treatment }\end{array}$} & \multirow{2}{*}{$\begin{array}{c}\text { Biomass Treating } \\
\text { Condition }\end{array}$} & \multirow{2}{*}{$\begin{array}{c}\text { Solid } \\
\text { Recovery }^{1)}(\%)\end{array}$} & \multirow{2}{*}{$\begin{array}{l}\text { O.D.W }{ }^{2)} \\
\text { (g) }\end{array}$} & \multicolumn{6}{|c|}{ Rate of Component $(\%, \mathrm{w} / \mathrm{w})$ and Weight $(\mathrm{g})$} \\
\hline & & & & Glucan & Xylan & Galactan & Arabinan & Mannan & AlL $^{3)}$ \\
\hline \multirow{2}{*}{$\begin{array}{l}\text { Unpre- } \\
\text { treated }\end{array}$} & Quercus mongolica & - & - & 45.4 & 19.4 & 2.5 & 2.5 & 2.1 & 18.1 \\
\hline & Pinus densiflora & - & - & 43.6 & 19.8 & 2.7 & 2.2 & 3.5 & - \\
\hline \multirow{7}{*}{$\begin{array}{l}\text { Steam- } \\
\text { explosion }\end{array}$} & $\begin{array}{l}\text { Quercus mongolica } \\
\left(25 \mathrm{kgf} / \mathrm{cm}^{2}, 3 \mathrm{~min}\right)\end{array}$ & 97 & 0.288 & $37.73(0.109)$ & $9.65(0.028)$ & $\mathrm{ND}^{4)}$ & ND & $1.93(0.006)$ & $32.75(0.094)$ \\
\hline & $\begin{array}{l}\text { Quercus mongolica } \\
\left(25 \mathrm{kgf} / \mathrm{cm}^{2}, 5 \mathrm{~min}\right)\end{array}$ & 95 & 0.290 & $40.63(0.112)$ & $7.37(0.022)$ & ND & ND & $1.81(0.006)$ & $34.48(0.100)$ \\
\hline & $\begin{array}{l}\text { Quercus mongolica } \\
\left(25 \mathrm{kgf} / \mathrm{cm}^{2}, 7 \mathrm{~min}\right)\end{array}$ & 90 & 0.293 & $42.71(0.114)$ & $4.60(0.013)$ & ND & ND & $1.65(0.005)$ & $36.16(0.107)$ \\
\hline & $\begin{array}{l}\text { Quercus mongolica } \\
\left(25 \mathrm{kgf} / \mathrm{cm}^{2}, 13 \mathrm{~min}\right)\end{array}$ & 87 & 0.294 & $47.03(0.138)$ & $0.75(0.002)$ & ND & ND & ND & $41.04(0.121)$ \\
\hline & $\begin{array}{c}\text { Pinus densiflora } \\
\text { (25kgf/cm², 3min) }\end{array}$ & 98 & 0.289 & $30.88(0.90)$ & $2.18(0.006)$ & ND & ND & $5.50(0.016)$ & $38.24(0.111)$ \\
\hline & $\begin{array}{c}\text { Pinus densiflora } \\
\left(25 \mathrm{kgf} / \mathrm{cm}^{2}, 7 \mathrm{~min}\right)\end{array}$ & 95 & 0.257 & $32.93(0.093)$ & $1.93(0.005)$ & ND & ND & $4.85(0.012)$ & $45.45(0.117)$ \\
\hline & $\begin{array}{c}\text { Pinus densiflora } \\
\left(25 \mathrm{kgf} / \mathrm{cm}^{2}, 13 \mathrm{~min}\right)\end{array}$ & 90 & 0.263 & $34.71(0.101)$ & $0.62(0.002)$ & ND & ND & $2.11(0.006)$ & $50.38(0.132)$ \\
\hline
\end{tabular}


For hemicellulose, the arabinan and galactan contents in the steam-exploded Korean Mongolian oak and Korean red pine vanished entirely even at a short treatment time of $3 \mathrm{~min}$. The mannan content in the stream-exploded Korean Mongolian oak was $1.65 \%(0.005 \mathrm{~g})$ at a steam treatment time of $7 \mathrm{~min}$, but it was entirely degraded in $13 \mathrm{~min}$ of treatment time. In the steam-exploded Korean red pine, the mannan content was not entirely vanished even at the longest treatment time of $13 \mathrm{~min}$. According to some references, temperature increases approximately $230{ }^{\circ} \mathrm{C}$ causes increased degradation in xylan, mannan, and galactan (Ruiz et al. 2008). A similar tendency with these results was observed in this study for steam-explosion pretreatment at approximately $225^{\circ} \mathrm{C}$.

The acid insoluble lignin (AIL) ranged between $33 \%$ and $41 \%$ in the steamexploded Korean Mongolian oak, and it ranged between 38\% and 50\% in the steamexploded Korean red pine. These high AIL contents can be explained by an increase in the relative composition rate from the hemicellulose evanesce and are characteristics of the steam-explosion pretreatment, these values showed similar results in the related references (Berlin et al. 2005; Ruiz et al. 2008; Kumar et al. 2010).

The solids recovery (\%) in steam-exploded Korean Mongolian oak and Korean red pine showed a high recovery between $87 \%$ and $98 \%$. These results are similar values in the references showing that the lignocellulosic biomass exhibited a higher solid recovery than a low recovery of $35 \%$ to $65 \%$ of the herbaceous biomass (Ruiz et al. 2008; Elliston et al. 2015).

\section{Optimization of Wood Biomass Saccharification Condition Using Saccharification Enhancer}

Optimization of saccharification of pretreated Korean Mongolian oak by steam-explosion using the $B B D$

To determine the maximum saccharification rate of steam-exploded Korean Mongolian oak, optimization of the saccharification factors using the BBD was conducted in 30 experiments, and the experiment design and saccharification rate are shown in Table 2. The multi-dimension equation to the used model is as follows:

Reduced sugar $(\%)=-81.6+24.19 X_{1}+4.023 X_{2}+0.0890 X_{3}-1.521 X_{1} * X_{1}-0.05170 X_{2} * X_{2}$ $-0.000044 X_{3} * X_{3}-0.0053 X_{1} * X_{2}-0.00574 X_{1} * X_{3}-0.000194 X_{2} * X_{3}$

where $X_{1}, X_{2}$, and $X_{3}$ are the substrate concentration, enzyme concentration, and saccharification enhancer, respectively. To confirm the interaction between each factor for enzyme hydrolysis of the steam-exploded Korean Mongolian oak and determine the optimum level of each variable for maximum yield, the analyzed response surface plot is shown in Figs. 2 through 4.

As shown in Fig. 2, when the added amount of saccharification enhancer was at the center point, the saccharification rate of the Korean Mongolian oak showed a low saccharification rate at a low level of substrate concentration (3\% to 6\%) and the enzyme concentration (10 to $20 \mathrm{FPU}$ ), but the saccharification rate increased significantly with an increase in the substrate concentration and enzyme concentration. The saccharification rate reached a maximum value at a substrate concentration of $7 \%$ and did not increase with an increase in the substrate concentration. One of the main factors influenced by enzyme hydrolysis rate of cellulose, a high substrate concentration, has been reported to cause low hydrolysis rate, byproduct inhibition, enzyme inactivation, and reduction of substrate response of cellulose (Gregg and Saddler 1996; Binod et al. 2011; Sindhu et al. 2014, 2016). At an optimum substrate concentration of $7 \%$, the enzyme concentration, which is the maximum saccharification rate, was 37.47 FPU. 


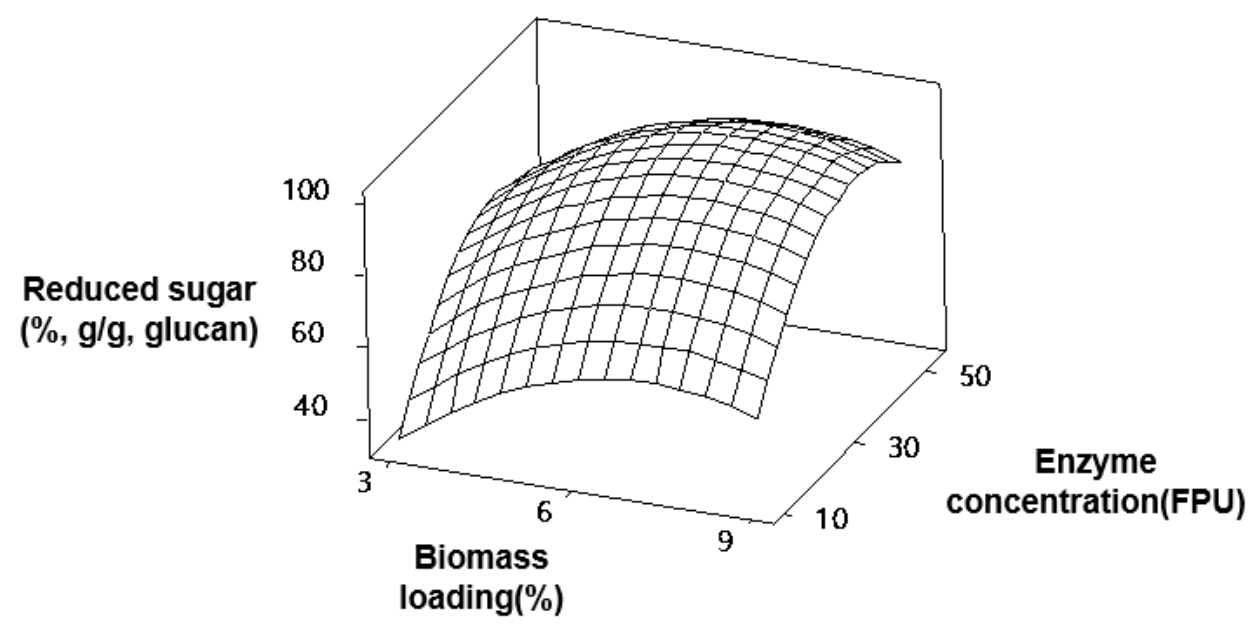

Fig. 2. Effect of biomass loading and enzyme concentration on reduced sugar for Quercus mongolica

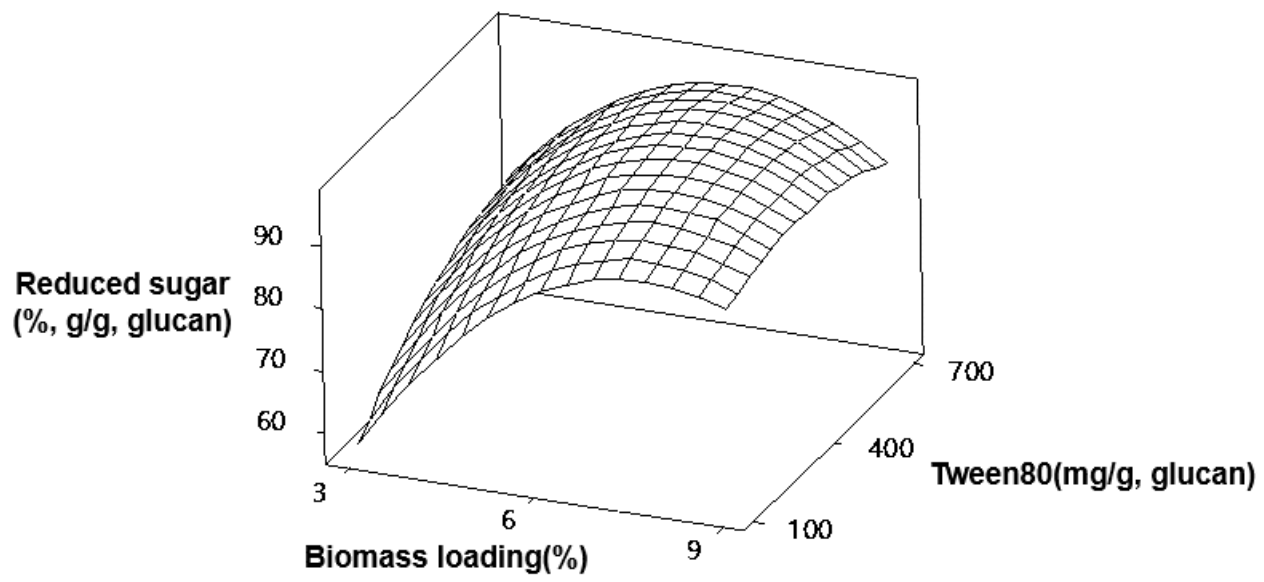

Fig. 3. Effect of biomass loading and surfactant concentration on reduced sugar for Quercus mongolica

As shown in Fig. 3, when the enzyme concentration was at the center point, saccharification rate of the Korean Mongolian oak was high at a high level of substrate concentration (6\% to $8 \%$ ) and added amount of the saccharification enhancer (400 to 500 $\mathrm{mg} / \mathrm{g}$-glucan). At an optimum substrate concentration of $7 \%$, the added amount of saccharification enhancer showed a maximum saccharification rate of $475.8 \mathrm{mg} / \mathrm{g}$-glucan, and an increased added amount of saccharification enhancer significantly influenced the saccharification rate. These results can be explained by improving the hydrolysis efficiency as saccharification enhancers modify substrate surfaces, unproductive adsorption and prevention of enzyme, or prevention of enzyme degradation during enzyme hydrolysis (Kim 2011; Sindhu et al. 2014).

As shown in Fig. 4, when the substrate concentration was at the center point, the saccharification rate of Korean Mongolian oak was at a high level of 30 to 40 FPU enzyme concentration and an added amount of 400 to $500 \mathrm{mg} / \mathrm{g}$-glucan saccharification enhancer. 


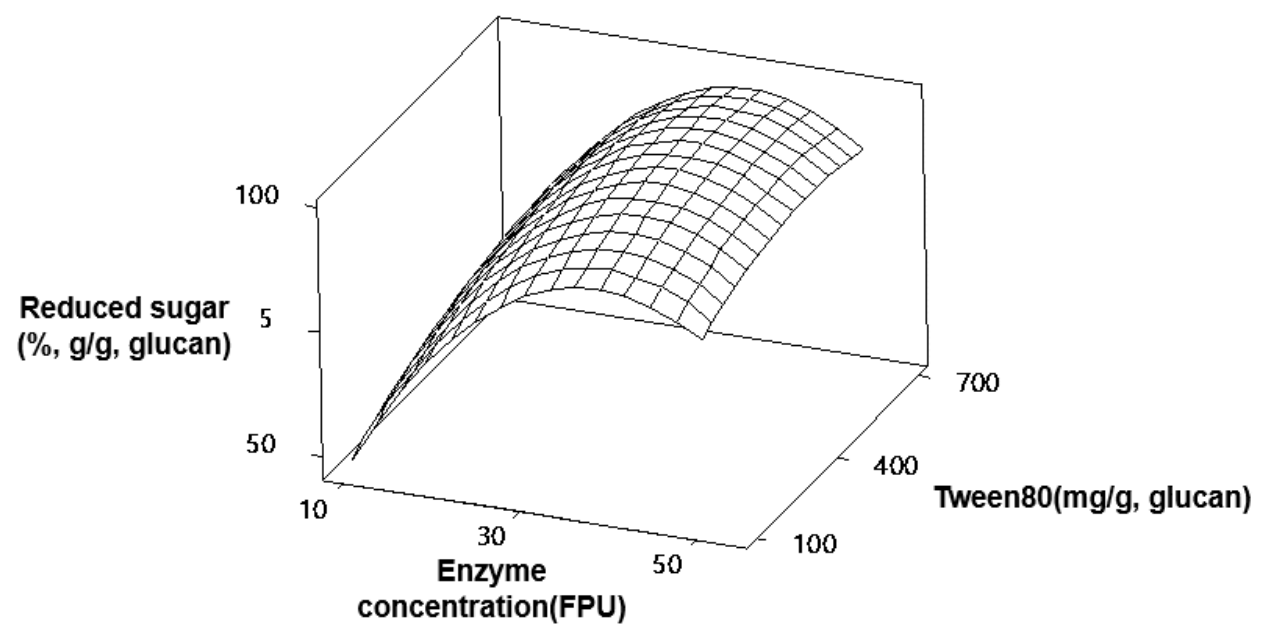

Fig. 4. Effect of enzyme concentration and surfactant concentration on reduced sugar for Quercus mongolica

At an optimum enzyme concentration of 34.47 FPU, the added amount of saccharification enhancer showed a maximum saccharification rate of $475.76 \mathrm{mg} / \mathrm{g}$-glucan, thus increasing the added amount of saccharification enhancer caused an uprise to the saccharification rate. These results demonstrated that the saccharification enhancer significantly influenced the steam-exploded Korean Mongolian oak. The ionic saccharification enhancer (polysorbate 80) used in this study has been reported to improve hydrolysis speed, and a similar level of increase was confirmed in this study (Castanon and Wilke, 1981; Helle et al. 1993). The results from the optimization experiment of the saccharification factors using BBD to determine the maximum saccharification rate of the steam-exploded Korean Mongolian oak showed 7\% substrate concentration, 37.47 FPU enzyme concentration, and an added amount of $475.76 \mathrm{mg} / \mathrm{g}$-glucan saccharification enhancer.

Statistically significant results of the experimental data by ANOVA using the Minitab 17 is shown in Table 4. For incompatibility, the p-value of saccharification was 0.502 , and this value was not significantly compatible to the $p$-value $(\mathrm{p}<0.05)$ of the Ftest, which showed a value greater than 0.05 . These results suggested that the model experimental data were consistent with the model predicted value, and the determination coefficient of 0.892 indicated that the saccharification rate significantly correlated with the substrate concentration, enzyme concentration, and added amount of saccharification enhancer.

Table 4. ANOVA Table for Response Surface Model of Quercus mongolica

\begin{tabular}{|c|c|c|c|c|c|}
\hline Source & $\begin{array}{c}\text { Degrees of } \\
\text { freedom }\end{array}$ & $\begin{array}{c}\text { Adj. sum of } \\
\text { squares }\end{array}$ & $\begin{array}{c}\text { Adj. mean } \\
\text { squares }\end{array}$ & F-value & P-value \\
\hline Regression & 9 & 10725.7 & 1191.74 & 18.36 & 0.000 \\
\hline Linear & 3 & 6239.0 & 2079.68 & 32.04 & 0.000 \\
\hline Square & 3 & 4261.3 & 1420.44 & 21.88 & 0.000 \\
\hline Interaction & 3 & 225.4 & 75.12 & 1.16 & 0.351 \\
\hline Residual error & 20 & 1298.2 & 64.91 & & 0.502 \\
\hline Lack of fit & 3 & 163.5 & 54.54 & 0.82 & \\
\hline Pure error & 17 & 1134.7 & 66.75 & & \\
\hline Total & 29 & 12023.9 & \\
\hline \multicolumn{7}{|l|}{$\mathrm{R}$-Sq=89.20\%, R-Sq(adj)=84.34\% } \\
\hline
\end{tabular}


The saccharification rates at the substrate concentration, enzyme concentration, and added amount of saccharification enhancer were predicted within the range of the designed experiment using the multi-dimension regression equation obtained from the experimental data. Based on these results, the steam-exploded Korean Mongolian oak (25 $\mathrm{kgf} / \mathrm{cm}^{2}, 7 \mathrm{~min}$ ) was used to determine the maximum predictable saccharification rate of approximately $99.88 \%$ for three factors: $7.0 \%$ substrate concentration, 37.47 FPU enzyme concentration, and an added amount of (polysorbate 80) $475.76 \mathrm{mg} / \mathrm{g}$-glucan saccharification enhancer. To verify predictable saccharification rate of this model, the results of the saccharification at optimum conditions such as $7.0 \%$ substrate concentration, 37.47 FPU enzyme concentration, and added amount of (polysorbate 80) $475.76 \mathrm{mg} / \mathrm{g}-$ glucan saccharification enhancer are shown in Table 5. The predictable value $(99.88 \%)$ was similar to the experimental value $(96.27 \%)$; therefore it was confirmed that the optimum conditions by the drawn model were appropriate (Table 5).

Table 5. Model Predicted Value for Reduced Sugar (\%, g/g, glucan) under Optimum Conditions

\begin{tabular}{|c|c|c|c|c|}
\hline \multirow{2}{*}{$\begin{array}{c}\text { Biomass Loading } \\
(\%)\end{array}$} & $\begin{array}{c}\text { Enzyme } \\
\text { Concentration }\end{array}$ & \multirow{2}{*}{$\begin{array}{c}\text { Surfactant } \\
\text { Concentration } \\
\text { (FPU) }\end{array}$} & \multicolumn{2}{|c|}{ Reduced Sugar (\%, g/g, glucan) } \\
\cline { 5 - 5 } & (mg/ucan) & Predicted & Experimental \\
\hline 7.0 & 37.47 & 475.76 & 99.88 & 96.27 \\
\hline
\end{tabular}

Many cases of maximum reduction sugar at $63.4 \%$ for steam-exploded olive tree, $42.5 \%$ for steam-exploded vineyard pruning, and $81.2 \%$ for steam-exploded giant bamboo at optimum conditions were reported (Cara et al. 2008; Garcia-Aparicio, et al. 2011; Buratti et al. 2015). In Fagaceae, steam-exploded hornbeam (Ostrya carpinifolia) was reported to have a maximum reduction sugar at $67.8 \%$ under optimal conditions using the central composite design as for experiments, and the saccharification results of the control enzyme by Cellic CTec2 (Novozymes, Denmark) under optimization using the BBD were $63.7 \pm 2.1 \%, 74.5 \pm 2.6 \%$, and $66.6 \pm 1.5 \%$ for holm, turkey oak, and Downey oak, respectively (Cotana et al. 2015; Barbanera et al. 2018). Compared with the previous references, the saccharification result (96.27\%) of steam-exploded Korean Mongolian oak at optimal conditions drawn from this study was argued as an excellent result.

Optimization of saccharification of Korean red pine pretreated by steam-explosion using the Box-Behnken design

RSM has been successfully used to optimize the saccharification conditions of the steam-exploded softwood, and this method is advantageous due to a reduction in time, space, and staff (Sindhu et al. 2014).

To determine the maximum saccharification rate of the steam-exploded Korean red pine, optimization of the various saccharification factors using the BBD was conducted in 30 experiments, and the experiment design and saccharification rate are shown in Table 6. The multi-dimension equation to be used is as follows,

$$
\begin{aligned}
& \text { Reduced sugar }(\%)=-93.2+28.79 \mathrm{X}_{1}+3.196 \mathrm{X}_{2}+.0020 \mathrm{X}_{3} \\
& \quad-2.155 \mathrm{X}_{1} * \mathrm{X}_{1}-0.04009 \mathrm{X}_{2} * \mathrm{X}_{2}-0.000061 \mathrm{X}_{3} * \mathrm{X}_{3}-0.0588 \mathrm{X}_{1} * \mathrm{X}_{2} \\
& +0.00436 \mathrm{X}_{1} * \mathrm{X}_{3}+0.000256 \mathrm{X}_{2} * \mathrm{X}_{3}
\end{aligned}
$$

where $X_{1}, X_{2}$, and $X_{3}$ are the substrate concentration, enzyme concentration, and saccharification enhancer, respectively. To confirm the interaction between each factor for the enzyme hydrolysis of the steam-exploded Korean red pine and determine the optimal level of each variable for maximum yield, the analyzed response surface graphs are shown in Figs. 5 through 7. 
Table 6. Reduced Sugar (\%, g/g, glucan) for Individual Runs of the Box-Behnken Design on Pinus densiflora

\begin{tabular}{|c|c|c|c|c|}
\hline Run & $\begin{array}{c}\text { Substrate } \\
\text { Concentration } \\
(\%)\end{array}$ & $\begin{array}{c}\text { Enzyme } \\
\text { Concentration } \\
\text { (FPU) }\end{array}$ & $\begin{array}{c}\text { Tween80 } \\
\text { (mg/g,glucan) }\end{array}$ & $\begin{array}{l}\text { Reduced Sugar } \\
\text { (\%, g/g, glucan) }\end{array}$ \\
\hline 1 & 0 & 0 & 0 & 55.47 \\
\hline 2 & + & + & 0 & 30.18 \\
\hline 3 & 0 & - & - & 30.18 \\
\hline 4 & 0 & - & - & 22.77 \\
\hline 5 & 0 & - & + & 15.84 \\
\hline 6 & 0 & 0 & 0 & 48.53 \\
\hline 7 & 0 & + & + & 47.83 \\
\hline 8 & + & + & 0 & 34.45 \\
\hline 9 & 0 & + & - & 49.82 \\
\hline 10 & - & + & 0 & 29.39 \\
\hline 11 & + & 0 & + & 37.06 \\
\hline 12 & + & 0 & + & 46.10 \\
\hline 13 & 0 & + & + & 42.85 \\
\hline 14 & 0 & - & + & 15.05 \\
\hline 15 & + & - & 0 & 19.01 \\
\hline 16 & 0 & + & - & 50.63 \\
\hline 17 & - & - & 0 & 1.65 \\
\hline 18 & - & 0 & - & 25.29 \\
\hline 19 & 0 & 0 & 0 & 53.89 \\
\hline 20 & + & 0 & - & 34.28 \\
\hline 21 & + & 0 & - & 47.62 \\
\hline 22 & - & + & 0 & 20.56 \\
\hline 23 & + & - & 0 & 26.56 \\
\hline 24 & - & 0 & - & 31.28 \\
\hline 25 & - & 0 & + & 14.26 \\
\hline 26 & - & - & 0 & 1.34 \\
\hline 27 & 0 & 0 & 0 & 61.77 \\
\hline 28 & 0 & 0 & 0 & 59.88 \\
\hline 29 & - & 0 & + & 12.19 \\
\hline 30 & 0 & 0 & 0 & 55.63 \\
\hline
\end{tabular}

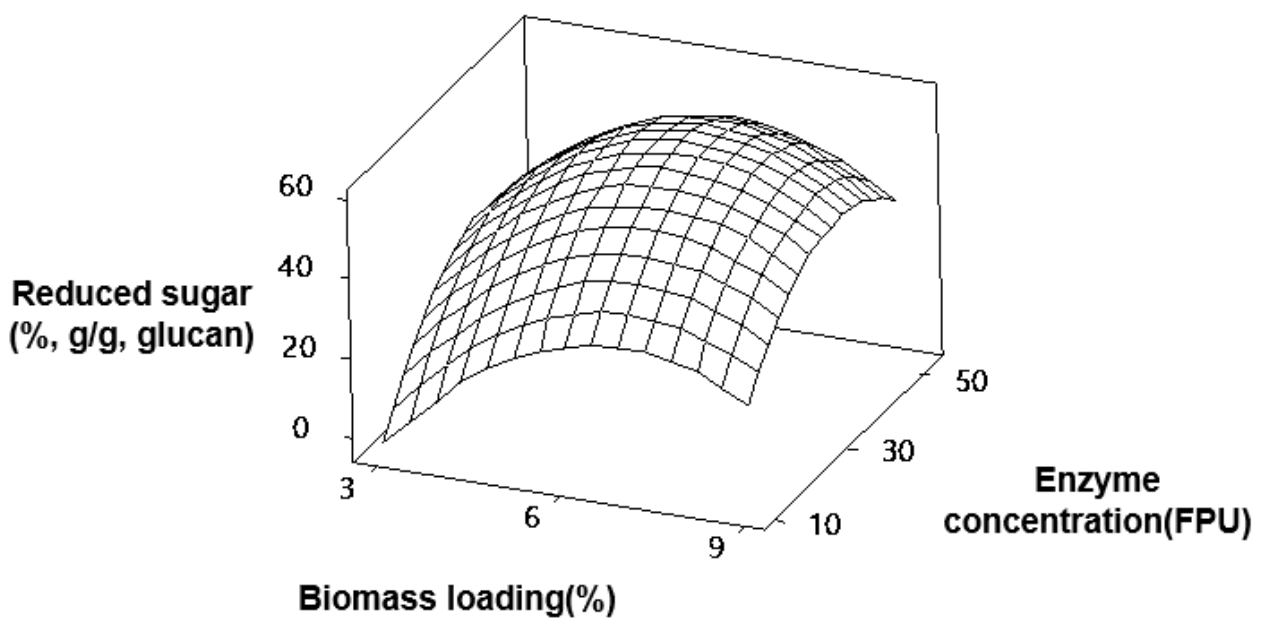

Fig. 5. Effect of biomass loading and enzyme concentration on reduced sugar for Pinus densiflora 


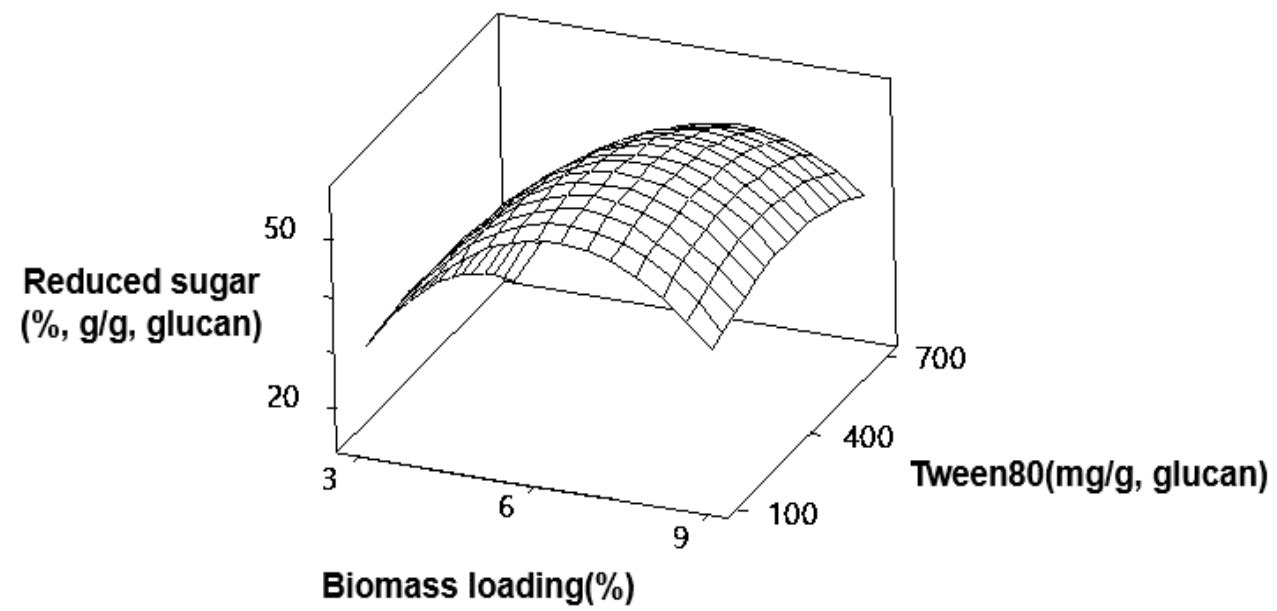

Fig. 6. Effect of biomass loading and surfactant concentration on reduced sugar for Pinus densiflora

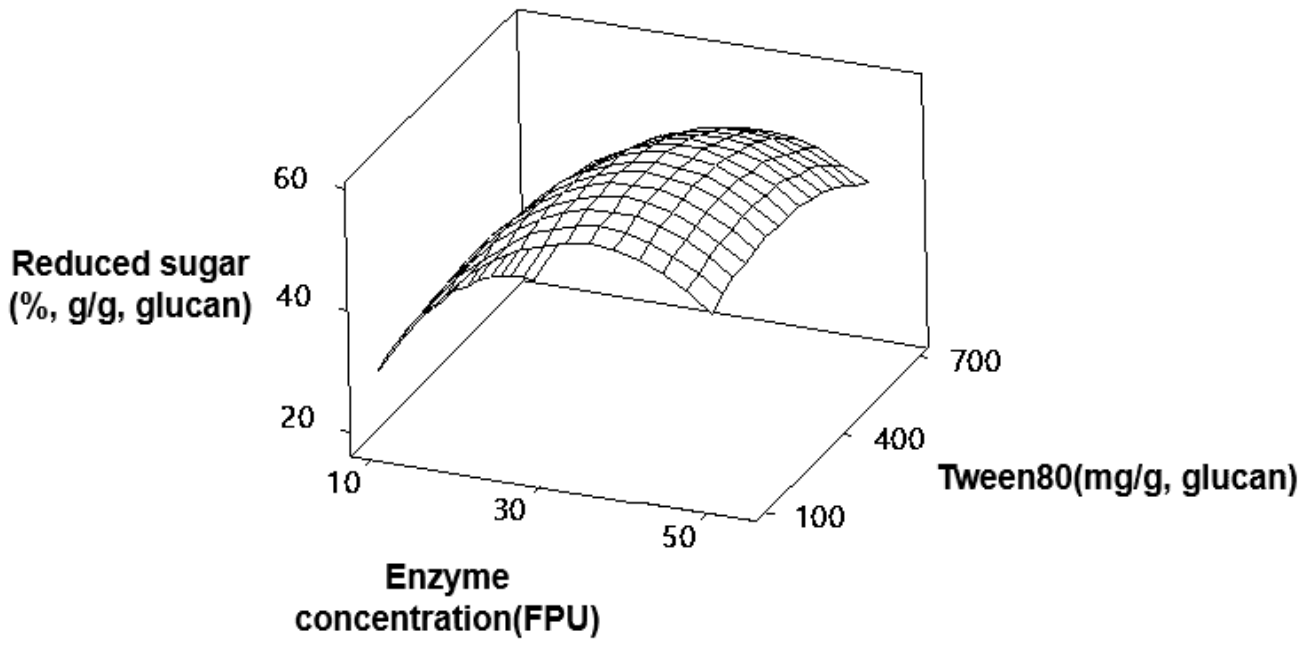

Fig. 7. Effect of enzyme concentration and surfactant concentration on reduced sugar for Pinus densiflora

As shown in Fig. 5, when the added amount of saccharification enhancer was in the center, the saccharification rate of Korean red pine showed a low saccharification rate at a low level of substrate concentration (3\% to 5\%) and enzyme concentration (10 to 20 FPU), but the saccharification rate increased significantly with an increase in the substrate and enzyme concentration. However, the saccharification rate decreased with an increase in enzyme concentration over a specific level (36.26 FPU), which can be explained using an inhibition reaction of feedback by glucose generated (Sindhu et al. 2011). At the optimal enzyme concentration of 36.26 FPU, substrate concentration, which indicates the maximum saccharification rate was $6.52 \%$.

As shown in Fig. 6, when the enzyme concentration was in the center point, the saccharification rate of Korean red pine showed a high saccharification rate at a high level of substrate concentration ( $6 \%$ to $7 \%$ ) and the added amount of the saccharification enhancer (300 to $400 \mathrm{mg} / \mathrm{g}$-glucan). Also an increase in the added amount of saccharification enhancer over the specific level (330.3 mg/g-glucan) decreased the saccharification rate. It was then decided that an inhibitory approach of enzyme to substrate by the formation of micelles decreased the saccharification rate (Jonstromer and Strey 1992; Schomacker and Strey 1994). A high substrate concentration has been reported as a factor that influences the enzymatic hydrolysis rate of cellulose, thereby causing low hydrolysis rate byproducts inhibition, enzyme inactivation, and response reduction of the 
cellulose substrate (Gregg and Saddler, 1996; Binod et al. 2012; Sindhu et al. 2014, 2016). However, Acanthophysium sp. KMF001 crude enzyme yielded a substrate concentration of $6.52 \%$, thereby exhibiting the maximum saccharification rate at the added amount of $330.3 \mathrm{mg} / \mathrm{g}$-glucan of the saccharification.

As shown in Fig. 7, when the substrate concentration was in the center point, the saccharification rate of the Korean red pine exhibited a high saccharification rate at a level of 30 to $40 \mathrm{FPU}$ enzyme concentration and an added amount of 300 to $400 \mathrm{mg} / \mathrm{g}$, glucan saccharification enhancer. At an optimum enzyme concentration of 32.26 FPU, the added amount of the saccharification enhancer revealed a maximum saccharification rate of 330.3 $\mathrm{mg} / \mathrm{g}$-glucan. The results from the optimization experiment of various saccharification factors using BBD to determine the maximum saccharification rate of the Korean red pine treated with steam-explosion showed $6.51 \%$ substrate concentration, 36.26 FPU enzyme concentration, and an added amount of $330.30 \mathrm{mg} / \mathrm{g}$-glucan saccharification enhancer for maximum saccharification rate.

Statistically significant results of the experimental data by ANOVA analysis using the Minitab 17 software are shown in Table 7.

Table 7. ANOVA Table for Response Surface Model of Pinus densiflora

\begin{tabular}{|c|c|c|c|c|c|}
\hline Source & $\begin{array}{c}\text { Degrees of } \\
\text { Freedom }\end{array}$ & $\begin{array}{c}\text { Adj. Sum of } \\
\text { Squares }\end{array}$ & $\begin{array}{c}\text { Adj. Mean } \\
\text { Squares }\end{array}$ & F-value & P-value \\
\hline Regression & 9 & 7974.41 & 886.05 & 34.10 & 0.000 \\
\hline Linear & 3 & 3319.23 & 1106.41 & 42.58 & 0.000 \\
\hline Square & 3 & 4413.66 & 1471.22 & 56.62 & 0.000 \\
\hline Interaction & 3 & 241.51 & 80.50 & 3.10 & 0.050 \\
\hline Residual error & 20 & 519.68 & 25.98 & & 0.124 \\
\hline Lack of fit & 3 & 146.04 & 46.68 & 2.21 & \\
\hline Pure error & 17 & 373.64 & 21.98 & & \\
\hline Total & 29 & 8494.09 & & \\
\hline \multicolumn{7}{|l|}{$\mathrm{R}$-Sq=93.88\%, R-Sq(adj)=91.13\% } \\
\hline
\end{tabular}

For incompatibility, the p-value of saccharification was 0.124 , and this value was not significantly compatible to the $\mathrm{p}$-value $(\mathrm{p}<0.05)$ of the F-test, which showed a value greater than 0.05 . These results suggested that the model experimental data were consistent with the model predicted value, and the determination coefficient of 0.9388 indicated that the saccharification rate significantly correlated with the substrate concentration, enzyme concentration, and the added amount of saccharification enhancer.

The saccharification rates at the substrate concentration, enzyme concentration, and the added amount of saccharification enhancer were predicted within the range of the designed experiment using the multi-dimension regression equation obtained from the experimental data. Based on these results, the Korean red pine $\left(25 \mathrm{kgf} / \mathrm{cm}^{2}\right)$ treated by steam-explosion $(7 \mathrm{~min}$ ) was used to determine the maximum predictable saccharification rate of approximately $58.73 \%$ at $6.52 \%$ substrate concentration, 36.26 FPU enzyme concentration, and an added amount of (polysorbate 80) $330.3 \mathrm{mg} / \mathrm{g}$-glucan saccharification enhancer. To verify the predicted saccharification rate of this model, the result from saccharification under optimal conditions such as substrate concentration $6.52 \%$, enzyme concentration $36.26 \mathrm{FPU}$, and addition amount of saccharification enhancer (polysorbate 80) $330.30 \mathrm{mg} / \mathrm{g}$, glucan is shown in Table 8. As shown in Table 8, the predicted value $(58.73 \%)$ was similar to the experimental value $(55.14 \%)$, therefore it was confirmed that the optimum conditions by the drawn model were appropriate. 
Table 8. Model Predicted Value for Reduced Sugar (\%, g/g, glucan) under Optimum Conditions

\begin{tabular}{|c|c|c|c|c|}
\hline \multirow{2}{*}{$\begin{array}{c}\text { Biomass Loading } \\
(\%)\end{array}$} & \multirow{2}{*}{$\begin{array}{c}\text { Enzyme } \\
\text { Concentration }\end{array}$} & \multirow{2}{*}{$\begin{array}{c}\text { Surfactant } \\
\text { Concentration } \\
\text { (FPU) }\end{array}$} & \multicolumn{2}{|c|}{ Reduced Sugar (\%, g/g, glucan) } \\
\cline { 4 - 5 } & (mg/glucan) & Predicted & Experimental \\
\hline 6.52 & 36.26 & 330.30 & 58.73 & 55.14 \\
\hline
\end{tabular}

A few reports regarding the application of saccharification to Korean red pine treated by the steam-explosion have been published, and these studies mainly used leaves or branches of softwood rather than the xylem of softwood. In the results determining optimum saccharification conditions of softwood leaves pretreated by the surfactantassisted acid pretreatment (SAAP) and surfactant-assisted base pretreatment (SABP), it was reported that the SAAP obtained a 15\% substrate concentration, 75 FPU enzyme concentration, $0.12 \%$ added amount of saccharification enhancer, and $0.588 \mathrm{~g} / \mathrm{g}$ maximum reducing sugar, while the SABP obtained a $10 \%$ substrate concentration, 120 FPU enzyme concentration, $0.04 \%$ added amount of saccharification enhancer, and $0.477 \mathrm{~g} / \mathrm{g}$ maximum reducing sugar (Pandey and Negi 2015). The low enzyme concentration (36.26 FPU) as the optimum condition elicited in this study and the Korean red pine treated by steamexplosion yielded a high saccharification rate $(55.14 \%)$, the saccharification ability of the crude enzyme from Acanthophysium sp. KMF001 performed excellently. For the enzyme hydrolysis result of the spruce pretreated by steam-explosion, it has been reported that the addition of saccharification enhancers improved saccharification yield of cellulose (Eriksson et al. 2002). For lignocellulose enzyme hydrolysis, there is an increase when nonionic saccharification enhancers and polymers including poly(ethylene oxide) were added (Börjesson et al. 2007a 2007b). Some researchers have reported that the addition of polysorbate 20 and poly(ethylene) glycol 4000 resulted in the maximum rates of hydrolysis in pretreated rock-rose (Börjesson et al. 2007a, b). Therefore, the necessity for the determination of appropriate saccharification enhancers and pretreatment processes for softwoods is suggested.

\section{Saccharification of Wood Biomass Under Optimum Saccharification Conditions}

Saccharification of Korean Mongolian oak pretreated by steam-explosion under optimum saccharification conditions

The results of saccharification for the Korean Mongolian oak pretreated by steamexplosion under optimum saccharification elicited in the previous section (Optimization of saccharification for pretreated Korean Mongolian oak by steam-explosion using the BoxBehnken design) are shown in Fig. 8. The Acanthophysium sp. KMF002 crude enzyme exhibited a saccharification extent of $84.46 \%$ for cellulose, having a higher saccharification compared to the corresponding value of $75.37 \%$ for the commercial enzyme (Reference I) 60 FPU (Fig. 8). Under the application in steam-exploded oak woods, the saccharification extent showed different results depending on the steam-explosion conditions. In oak woods without saccharification enhancers, those pretreated for 3, 5, 7, and 13 min of steamexplosion showed a saccharification of approximately $20 \%$ to $60 \%$, which was a lower value compared with the commercial enzyme. However, when the saccharification enhancer was used under optimum conditions elicited from the BBD, the saccharification showed a high result of approximately $91 \%$ and $96 \%$ at a steam-explosion treatment time of 5 and $7 \mathrm{~min}$, respectively, and these were excellent results compared with commercial enzymes. These results suggested that the saccharification conditions elicited from the experimental design for the optimization of various factors using BBD to determine the maximum saccharification rate significantly improved the saccharification ability of oak substrate pretreated by the steam-explosion. 


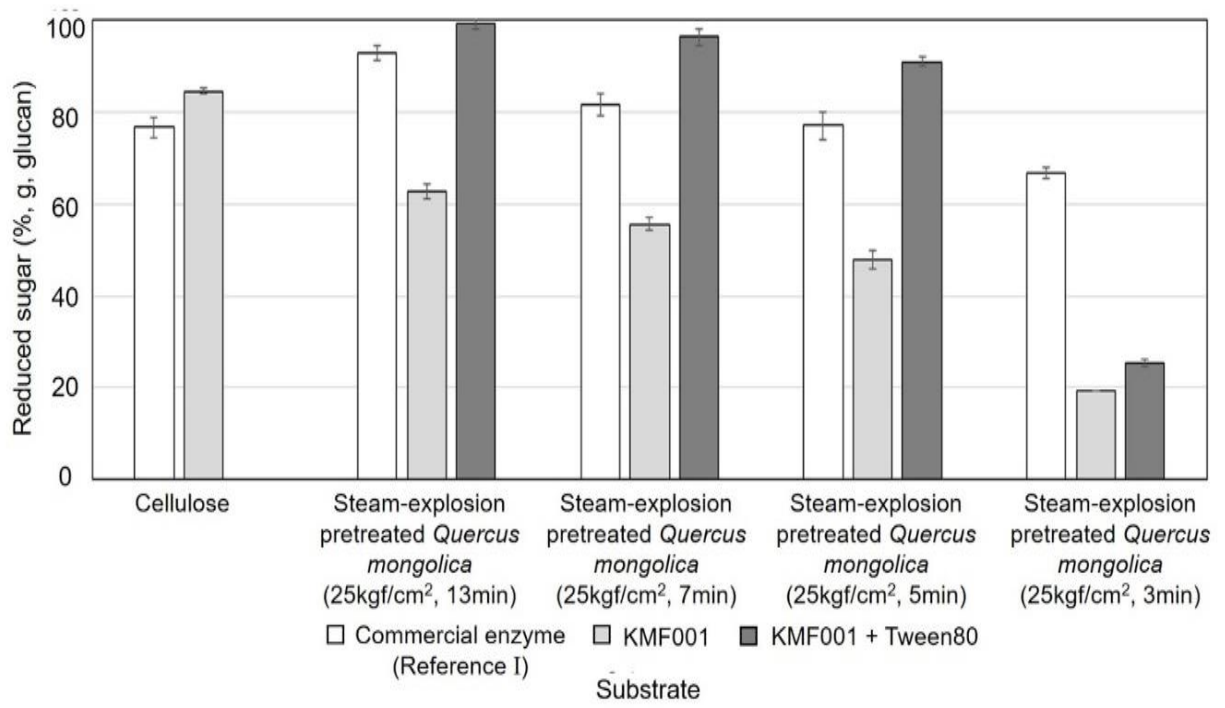

Fig. 8. Reduced sugar of oak pretreated by steam-explosion $\left(25 \mathrm{kgf} / \mathrm{cm}^{2}, 13,7,5,3 \mathrm{~min}\right)$ and cellulose by commercial enzyme (Reference I ) or Acanthophysium sp. KMF001

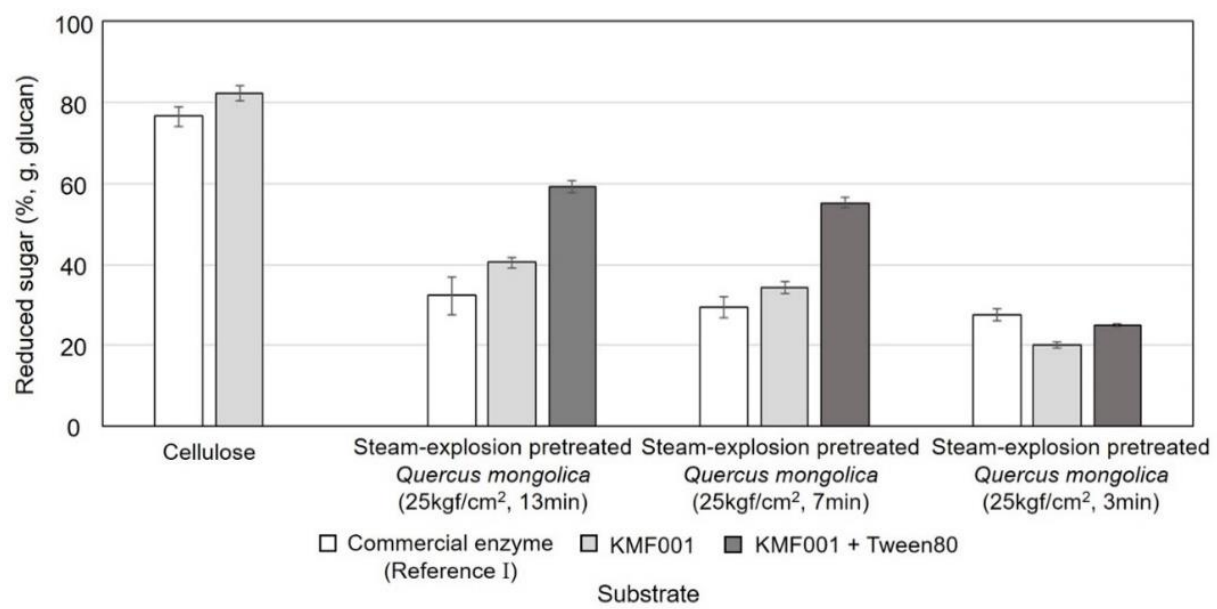

Fig. 9. Reduced sugar of pine pretreated by steam-explosion $\left(25 \mathrm{kgf} / \mathrm{cm}^{2}, 13,7,3 \mathrm{~min}\right)$ and cellulose by commercial enzyme (Reference I ) or Acanthophysium sp. KMF001

Saccharification of Korean red pine pretreated by steam-explosion under optimum saccharification conditions

The results for the saccharification of Korean Mongolian oak pretreated under various steam-explosion conditions by application of the optimum saccharification conditions elicited in the previous section (Optimization of saccharification for Korean red pine pretreated by steam-explosion using the Box-Behnken design) are shown in Fig. 9. In the oak woods without saccharification enhancers, as shown in Fig. 9, the pine wood pretreated for 3 and 7 min of steam-explosion showed a saccharification of $20 \%$ and $34 \%$, respectively, and the pine wood with 13 min of steam-explosion showed low saccharification of approximately $40 \%$ compared with cellulose. However, when the saccharification enhancer was used under optimum conditions elicited from the BBD, the saccharification rates showed an increase of approximately 20\% to 55\% and 59\% for steam-explosion treatment of $7 \mathrm{~min}$ and $13 \mathrm{~min}$, respectively. A positive effect of the surfactant usage on saccharification can be explained that the presence of surfactants contribute to decrease non-productive binding of cellulase, make rapid desorption of the enzyme from the substrate, avoid enzyme inactivation, and increase enzyme stability during the enzyme hydrolysis (Xiao et al. 2020). 
Table 4. Chemical Composition (\%) and Concentration of Polymeric Sugars (g) of Pretreated Wood Biomass under Different Conditions

\begin{tabular}{|c|c|c|c|c|c|c|c|c|c|}
\hline \multirow{2}{*}{$\begin{array}{c}\text { Pre- } \\
\text { Treatment }\end{array}$} & \multirow{2}{*}{$\begin{array}{c}\text { Biomass Treating } \\
\text { Condition }\end{array}$} & \multirow{2}{*}{$\begin{array}{c}\text { Solid } \\
\text { Recovery }{ }^{1)}(\%)\end{array}$} & \multirow{2}{*}{$\begin{array}{l}\text { O.D.W2) } \\
\text { (g) }\end{array}$} & \multicolumn{6}{|c|}{ Rate of Component $(\%, \mathrm{w} / \mathrm{w})$ and Weight $(\mathrm{g})$} \\
\hline & & & & Glucan & Xylan & Galactan & Arabinan & Mannan & AlL $^{3)}$ \\
\hline \multirow{2}{*}{$\begin{array}{l}\text { Unpre- } \\
\text { treated }\end{array}$} & Quercus mongolica & - & - & 45.4 & 19.4 & 2.5 & 2.5 & 2.1 & 18.1 \\
\hline & Pinus densiflora & - & - & 43.6 & 19.8 & 2.7 & 2.2 & 3.5 & - \\
\hline \multirow{7}{*}{$\begin{array}{l}\text { Steam- } \\
\text { explosion }\end{array}$} & $\begin{array}{c}\text { Quercus mongolica } \\
\left(25 \mathrm{kgf} / \mathrm{cm}^{2}, 3 \mathrm{~min}\right)\end{array}$ & 97 & 0.288 & $37.73(0.109)$ & $9.65(0.028)$ & $\mathrm{ND}^{4)}$ & ND & $1.93(0.006)$ & $32.75(0.094)$ \\
\hline & $\begin{array}{l}\text { Quercus mongolica } \\
\left(25 \mathrm{~kg} / \mathrm{cm}^{2}, 5 \mathrm{~min}\right)\end{array}$ & 95 & 0.290 & $40.63(0.112)$ & $7.37(0.022)$ & ND & ND & $1.81(0.006)$ & $34.48(0.100)$ \\
\hline & $\begin{array}{l}\text { Quercus mongolica } \\
\text { (25kgf/cm², 7min) }\end{array}$ & 90 & 0.293 & $42.71(0.114)$ & $4.60(0.013)$ & ND & ND & $1.65(0.005)$ & $36.16(0.107)$ \\
\hline & $\begin{array}{l}\text { Quercus mongolica } \\
\text { (25kgf/cm², } 13 \mathrm{~min})\end{array}$ & 87 & 0.294 & $47.03(0.138)$ & $0.75(0.002)$ & ND & ND & ND & $41.04(0.121)$ \\
\hline & $\begin{array}{c}\text { Pinus densiflora } \\
\left(25 \mathrm{kgf} / \mathrm{cm}^{2}, 3 \mathrm{~min}\right)\end{array}$ & 98 & 0.289 & $30.88(0.90)$ & $2.18(0.006)$ & ND & ND & $5.50(0.016)$ & $38.24(0.111)$ \\
\hline & $\begin{array}{c}\text { Pinus densiflora } \\
\text { (25kgf/cm², } 7 \mathrm{~min})\end{array}$ & 95 & 0.257 & $32.93(0.093)$ & $1.93(0.005)$ & ND & ND & $4.85(0.012)$ & $45.45(0.117)$ \\
\hline & $\begin{array}{c}\text { Pinus densiflora } \\
\left(25 \mathrm{kgf} / \mathrm{cm}^{2}, 13 \mathrm{~min}\right)\end{array}$ & 90 & 0.263 & $34.71(0.101)$ & $0.62(0.002)$ & ND & ND & $2.11(0.006)$ & $50.38(0.132)$ \\
\hline
\end{tabular}


These results indicated that the Acanthophysium sp. KMF001 crude enzyme has a relatively low saccharification extent compared with the aforementioned Korean Mongolian oak or cellulose, but it was evaluated to have a high saccharification ability compared with the commercial enzyme. The improvement of saccharification is difficult because of their significantly high lignin contents compared with the oak woods. Zhu et al. (2009) reported that a hydrolysis rate over $90 \%$ was obtained from spruce and red pine wood chips pretreated using the disk-refining process to reduce chip size after sulfite treatment under acidic conditions (Sannigrahi et al. 2010). They reported that the use of ethanol organosolv-pretreated loblolly pine to enhance enzyme hydrolysis efficiency obtained a high sugar yield of $70 \%$. These reports suggested that the steam-explosion pretreatment process was still unsatisfactory to improve saccharification ability of domestic pine woods compared with pretreatment methods using acid or organic solvents. To improve saccharification ability of softwoods such as domestic pine woods using Acanthophysium sp. KMF001 crude enzyme, there is a need to determine the appropriate pretreatment methods for softwoods.

\section{CONCLUSIONS}

1. In Korean Mongolian oak $\left(25 \mathrm{kgf} / \mathrm{cm}^{2}\right)$ pretreated for $7 \mathrm{~min}$, the optimum conditions were a 7\% substrate concentration, 37.47 FPU enzyme concentration, and 475. 76 $\mathrm{mg} / \mathrm{g}$-glucan saccharification enhancer (polysorbate 80) concentration, and the maximum saccharification rate was $99.88 \%$. In Korean red pine $\left(25 \mathrm{kgf} / \mathrm{cm}^{2}\right)$ pretreated for $7 \mathrm{~min}$, the optimum conditions were a $6.52 \%$ substrate concentration, 36.26 FPU enzyme concentration, and $330.3 \mathrm{mg} / \mathrm{g}$-glucan saccharification enhancer (polysorbate 80 ) concentration, and the maximum saccharification rate was $58.73 \%$. The results of saccharification under optimum saccharification conditions elicited from oak and pine wood pretreated by various steam-explosion conditions showed a result of approximately $10 \%$ to $15 \%$ higher compared with the commercial enzyme. However, the domestic pine wood pretreated with the steam-explosion process showed a lower saccharification rate than the pretreatments using acids or organic solvents in the references. Therefore, using the Acanthophysium sp. KMF001 crude enzyme presented the need for the application of other appropriate pretreatment methods.

2. Korean Mongolian oak and Korean red pine pretreated by steam-explosion diminished a little hemicellulose contents, but the results for the extent of saccharification and enzyme hydrolysis of cellulose were increased. Also, it was confirmed that the substrate concentration, enzyme concentration, and addition amount of saccharification enhancer were important factors in enzymatic saccharification of Korean lignocellulosic biomass pretreated with steam-explosion using the BBD experimental design. This experimental design was used to predict the enzyme hydrolysis yield of lignocellulosic biomass substrate pretreated by steam-explosion. It was confirmed that the nonionic saccharification enhancer, polysorbate 80, is an appropriate saccharification enhancer to the Acanthophysium sp. KMF001 applied in Korean oak wood. As the Acanthophysium sp. KMF001 exhibited an excellent saccharification rate of lignocellulosic biomass, the performance of Acanthophysium sp. KMF001 was evaluated to have a high feasibility for commercialization. 


\section{ACKNOWLEDGEMENTS}

This study was conducted with the support of 'R\&D Program for Forest Science Technology (Project No. 2020261B10-2022_AC02, 2019150B10-2023-0301, and 2013070E10-1919-AA03)' all provided by Korea Forest Service (Korea Forestry Promotion Institute).

\section{REFERENCES CITED}

Alkasrawi, M., Eriksson, T., Börjesson, J., Wingren, A., Galbe, M., Tjerneld, F., and Zacchi, G. (2003). "The effect of Tween-20 on simultaneous saccharification and fermentation of softwood to ethanol," Enzyme and Microbial Technology 33(1), 71-78. DOI: 10.1016/S0141-0229(03)00087-5

Ballesteros, I., Negro, M. J., Oliva, J. M., Cabañas, A., Manzanares, P., and Ballesteros, M. (2006). "Ethanol production from steam-explosion pretreated wheat straw. In Twenty-seventh symposium on biotechnology for fuels and chemicals," Humana Press. 496-508. DOI: /10.1007/978-1-59745-268-7 41

Ballesteros, I., Oliva, J. M., Carrasco, J., Cabanas, A., Navarro, A. A., and Ballesteros, M. (1998). "Effect of surfactants and zeolites on simultaneous saccharification and fermentation of steam-exploded poplar biomass to ethanol," Appl. Biochem. Biotechnol. 70(1), 369. DOI: 10.1007/978-1-4612-1814-2_35

Barbanera, M., Lascaro, E., Foschini, D., Cotana, F., and Buratti, C. (2018). "Optimization of bioethanol production from steam exploded hornbeam wood (Ostrya carpinifolia) by enzymatic hydrolysis," Renewable Energy 124, 136-143. DOI: 10.1016/j.renene.2017.07.022

Berlin, A., Gilkes, N., Kilburn, D., Bura, R., Markov, A., Skomarovsky, A., Okunev, O., Gusakov, A., Maximenko, V., Gregg, D., Sinitsyn, A., and Saddler, J. (2005). "Evaluation of novel fungal cellulase preparations for ability to hydrolyze softwood substrates - Evidence for the role of accessory enzymes," Enzyme and Microbial Technology 37(2), 175-184. DOI: 10.1016/j.enzmictec.2005.01.039

Binod, P., Janu, K.U., Sindhu, R., and Pandey, A. (2011). "Hydrolysis of lignocellulosic biomass for bioethanol production," in: Biofuels: Alternative Feedstocks and Conversion Processes, A. Pandey, C. Larroche, S. C. Ricke, (Eds.), Elsevier, Amsterdam, pp. 229-250.

Biswas, A. K., Umeki, K., Yang, W., and Blasiak, W. (2011). "Change of pyrolysis characteristics and structure of woody biomass due to steam explosion pretreatment," Fuel Processing Technology 92(10), 1849-1854. DOI: 10.1016/j.fuproc.2011.04.038

Börjesson, J., Engqvist, M., Sipos, B., and Tjerneld, F. (2007a). "Effect of poly (ethylene glycol) on enzymatic hydrolysis and adsorption of cellulase enzymes to pretreated lignocellulose," Enzyme and Microbial Technology 41(1-2), 186-195. DOI: $10.1016 /$ j.enzmictec.2007.01.003

Börjesson, J., Peterson, R., and Tjerneld, F. (2007b). "Enhanced enzymatic conversion of softwood lignocellulose by poly (ethylene glycol) addition," Enzyme and Microbial Technology 40(4), 754-762. DOI: 10.1016/j.enzmictec.2006.06.006

Buratti, C., Barbanera, M., and Lascaro, E. (2015). "Ethanol production from vineyard pruning residues with steam explosion pretreatment," Environmental Progress \& Sustainable Energy 34(3), 802-809. DOI: 10.1002/ep.12043

Cara, C., Ruiz, E., Ballesteros, M., Manzanares, P., Negro, M. J., and Castro, E. 
(2008). "Production of fuel ethanol from steam-explosion pretreated olive tree pruning," Fuel 87, 692-700. DOI: 10.1016/j.fuel.2007.05.008

Castanon, M., and Wilke, C. R. (1981). "Effects of the surfactant Tween 80 on enzymatic hydrolysis of newspaper," Biotechnology and Bioengineering 23(6), 1365-1372. DOI: 10.1002/bit.260230615

Cotana, F., Buratti, C., Barbanera, M., and Lascaro, E. (2015). Optimization of the steam explosion and enzymatic hydrolysis for sugars production from oak woods," Bioresource Technology 198, 470-477. DOI:

10.1016/j.biortech.2015.09.047

Datar, R., Huang, J., Maness, P. C., Mohagheghi, A., Czernik, S., and Chornet, E. (2007). Hydrogen production from the fermentation of corn stover biomass pretreated with a steam-explosion process," International Journal of Hydrogen Energy 32(8), 932-939. DOI: 10.1016/j.ijhydene.2006.09.027

Elliston, A., Wilson, D. R., Wellner, N., Collins, S. R., Roberts, I. N., and Waldron, K. W. (2015). "Effect of steam explosion on waste copier paper alone and in a mixed lignocellulosic substrate on saccharification and fermentation," Bioresource Technology 187, 136-143. DOI: 10.1016/j.biortech.2015.03.089

Eriksson, T., Börjesson, J., and Tjerneld, F. (2002). "Mechanism of surfactant effect in enzymatic hydrolysis of lignocellulose," Enzyme and Microbial Technology 31(3), 353-364. DOI: 10.1016/S0141-0229(02)00134-5

Garcia-Aparicio, M., Parawira, W., van Rensburg, E., Diedericks, D., Galbe, M., Rosslander, C., Zacchi, G., and Gorgens, J. (2011). "Evaluation of steam-treated giant bamboo for production of fermentable sugars," Biotechnology Progress 27, 641-649. DOI: 10.1002/btpr.580

Gregg, D. J., and Saddler, J. N. (1996). "Factors affecting cellulose hydrolysis and the potential of enzyme recycle to enhance the efficiency of an integrated wood to ethanol process," Biotechnology and Bioengineering 51, 375-383. DOI: 10.1002/(SICI)1097-0290(19960820)51:4<375::AID-BIT1>3.0.CO;2-F

Helle, S. S., Duff, S. J. B., and Cooper, D. G. (1993). "Effect of surfactants on cellulose hydrolysis," Biotechnology and Bioengineering 42, 611-617. DOI: 10.1002/bit.260420509

Jonstromer, M., and Strey, R. (1992). "Nonionic bilayer in dilute solutions - Effect of additives," Journal of Physical Chemistry 96, 5993-6000. DOI: $10.1021 / \mathrm{j} 100193 \mathrm{a} 064$

Kaar, W. E., and Holtzapple, M. T. (1998). "Benefits from Tween during enzymic hydrolysis of corn stover," Biotechnology and Bioengineering 59(4), 419-427. DOI: 10.1002/(SICI)1097-0290(19980820)59:4<419::AID-BIT4>3.0.CO;2-J

Karunanithy, C., and Muthukumarappan, K. (2011a). "Optimization of alkali soaking and extrusion pretreatment of prairie cord grass for maximum sugar recovery by enzymatic hydrolysis," Biochemical Engineering Journal 54(2), 71-82. DOI: 10.1016/j.bej.2011.02.001

Karunanithy, C., and Muthukumarappan, K. (2011b). "Optimization of switchgrass and extruder parameters for enzymatic hydrolysis using response surface methodology," Industrial Crops and Products 33(1), 188-199. DOI: 10.1016/j.indcrop.2010.10.008

Kim. Y. H. (2011). Study on the Influence Factors and Effect of Mediator on Enzymatic Saccharification of Lignocellulosic Biomass, Master's Thesis, Kookmin University, Seoul, South Korea.

Kim, Y. S., Kim, T. J., Shin, K., and Yoon, S. M. (2016). "Novel Acanthophysium sp. KMF001 having high cellulase activity," South Korea Patent No.

KR101621425B1 
Korea Forest Service. (2018). Statistical Yearbook of Forestry 2018, Korea Forest Service, Seoul, South Korea.

Kristensen, J. B., Börjesson, J., Bruun, M. H., Tjerneld, F., and Jørgensen, H. (2007). "Use of surface active additives in enzymatic hydrolysis of wheat straw lignocellulose," Enzyme and Microbial Technology 40(4), 888-895. DOI: 10.1016/j.enzmictec.2006.07.014

Kumar, L., Chandra, R., Chung, P. A., and Saddler, J. (2010). "Can the same steam pretreatment conditions be used for most softwoods to achieve good, enzymatic hydrolysis and sugar yields?," Bioresource Technology 101(20), 7827-7833. DOI: 10.1016/j.biortech.2010.05.023

Mooney, C. A., Mansfield, S. D., Touhy, M. G., and Saddler, J. N. (1998). "The effect of initial pore volume and lignin content on the enzymatic hydrolysis of softwoods," Bioresource Technology 64(2), 113-119. DOI: 10.1016/S09608524(97)00181-8

Pandey, A. K., and Negi, S. (2015). "Impact of surfactant assisted acid and alkali pretreatment on lignocellulosic structure of pine foliage and optimization of its saccharification parameters using response surface methodology," Bioresource Technology 192, 115-125. DOI: 10.1016/j.biortech.2015.04.054

Ruiz, E., Cara, C., Manzanares, P., Ballesteros, M., and Castro, E. (2008). "Evaluation of steam explosion pre-treatment for enzymatic hydrolysis of sunflower stalks. Enzyme and Microbial Technology 42(2), 160-166. DOI: 10.1016/j.enzmictec.2007.09.002

Salvi, D. A., Aita, G. M., Robert, D., and Bazan, V. (2010). "Ethanol production from sorghum by a dilute ammonia pretreatment," Journal of Industrial Microbiology \& Biotechnology 37(1) 27. DOI: 10.1007/s10295-009-0645-5

Sannigrahi, P., Miller, S. J., Ragauskas, A. J. (2010). "Effects of organosolv pretreatment and enzymatic hydrolysis on cellulose structure and crystallinity in Loblolly pine," Carbohydrate Research 345(7), 965-970. DOI: 10.1016/j.carres.2010.02.010

Schomacker, R., and Strey, R. (1994). "Effect of ionic surfactants on nonionic bilayers-bending elasticity of weakly charged membranes," Journal of Physical Chemistry 98, 3908-3912. DOI: 10.1021/j100065a055

Selig, M. J., Viamajala, S., Decker, S. R., Tucker, M. P., Himmel, M. E., and Vinzant, T. B. (2007). "Deposition of lignin droplets produced during dilute acid pretreatment of maize stems retards enzymatic hydrolysis of cellulose," Biotechnology Progress 23(6), 1333-1339. DOI: 10.1021/bp0702018

Sewalt, V. J. H., Glasser, W. G., and Beauchemin, K. A. (1997). "Lignin impact on fiber degradation. 3. Reversal of inhibition of enzymatic hydrolysis by chemical modification of lignin and by additives," Journal of Agricultural and Food Chemistry 45(5), 1823-1828. DOI: 10.1021/jf9608074

Sindhu, R., Binod, P., Janu, K. U., Sukumaran, R. K., and Pandey, A. (2012). "Organosolvent pretreatment and enzymatic hydrolysis of rice straw for the production of bioethanol," World Journal of Microbiology and Biotechnology 28(2), 473-483. DOI: 10.1007/s11274-011-0838-8

Sindhu, R., Kuttiraja, M., Binod, P., Janu, K. U., Sukumaran, R. K., and Pandey, A. (2011). "Dilute acid pretreatment and enzymatic saccharification of sugarcane tops for bioethanol production," Bioresource Technology 102(23), 10915-10921. DOI: 10.1016/j.biortech.2011.09.066 
Sindhu, R., Kuttiraja, M., Binod, P., Sukumaran, R. K., and Pandey, A. (2014). "Bioethanol production from dilute acid pretreated Indian bamboo variety (Dendrocalamus sp.) by separate hydrolysis and fermentation," Industrial Crops and Products 52, 169-176. DOI: 10.1016/j.indcrop.2013.10.021

Sindhu, R., Kuttiraja, M., Prabisha, T. P., Binod, P., Sukumaran, R. K., and Pandey, A. (2016). "Development of a combined pretreatment and hydrolysis strategy of rice straw for the production of bioethanol and biopolymer," Bioresource Technology 215, 110-116. DOI: 10.1016/j.biortech.2016.02.080

Sindhu, R., Kuttiraja, M., Preeti, V. E., Vani, S., Sukumaran, R. K., and Binod, P. (2013). "A novel surfactant-assisted ultrasound pretreatment of sugarcane tops for improved enzymatic release of sugars," Bioresource Technology 135, 67-72. DOI: 10.1016/j.biortech.2012.09.050

Singh, J., Suhag, M., and Dhaka, A. (2015). "Augmented digestion of lignocellulose by steam explosion, acid and alkaline pretreatment methods: A review," Carbohydrate Polymers 117, 624-631. DOI: 10.1016/j.carbpol.2014.10.012

Sipos, B., Dienes, D., Schleicher, Á., Perazzini, R., Crestini, C., Siika-Aho, M., and Réczey, K. (2010). "Hydrolysis efficiency and enzyme adsorption on steampretreated spruce in the presence of poly (ethylene glycol)," Enzyme and Microbial Technology 47(3), 84-90. DOI: 10.1016/j.enzmictec.2010.05.010

Sun, F., and Chen, H. (2007). "Evaluation of enzymatic hydrolysis of wheat straw pretreated by atmospheric glycerol autocatalysis," Journal of Chemical Technology \& Biotechnology 82(11), 1039-1044. DOI: 10.1002/jctb.1764

Sun, Y., and Cheng, J. (2002). "Hydrolysis of lignocellulosic materials for ethanol production: A review," Bioresource Technology 83(1), 1-11. DOI: 10.1016/S0960-8524(01)00212-7

Valchev, I., Nenkova, S., Tsekova, P., and Lasheva, V. (2009). "Use of enzymes in hydrolysis of maize stalks," BioResources 4(1) 285-291. DOI: 10.15376/BIORES.4.1.285-291

Xiao, W., Song, H., Li, H., Li, X., Yang, Y., Hu, P., Zhou, S., Hu, Y., Xu, X., Zhang, Z., and Jiang, Z. (2020). "Effect of different biological surfactants on engineering Saccharomyces cerevisiae in simultaneous saccharification and fermentation of corncob," BioResources 15(2), 2512-2524. DOI: 10.15376/biores.15.2.2512-2524

Yang, B., and Wyman, C. E. (2006). "BSA treatment to enhance enzymatic hydrolysis of cellulose in lignin containing substrates," Biotechnology and Bioengineering 94(4), 611-617. DOI: 10.1002/bit.20750

Yoshida, M., Liu, Y., Uchida, S., Kawarada, K., Ukagami, Y., Ichinose, H., Kaneko, S., and Fukuda, K. (2008). "Effects of cellulose crystallinity, hemicellulose, and lignin on the enzymatic hydrolysis of Miscanthus sinensis to monosaccharides," Bioscience, Biotechnology, and Biochemistry 72(3), 805-810. DOI: 10.1271/bbb.70689

Yoon, S. M., Park, S. H., Kim, T. J., Kim, Y. K., and Kim, Y. S. (2019). "Acanthophysium sp. KMF001, a new strain with high cellulase activity," Journal of the Korean Wood Science and Technology 46(6), 751-760. DOI: 10.5658/WOOD.2019.47.6.751

Zhang, Y. H. P., and Lynd, L. R. (2004). "Toward an aggregated understanding of enzymatic hydrolysis of cellulose: Noncomplexed cellulase systems.," Biotechnology and Bioengineering 88(7), 797-824. DOI: 10.1002/bit.20282 
Zhu, J. Y., Pan, X. J., Wang, G. S., and Gleisner, R. (2009). "Sulfite pretreatment (SPORL) for robust enzymatic saccharification of spruce and red pine," Bioresource Technology 100(8) 2411-2418. DOI: 10.1016/j.biortech.2008.10.057

Article submitted: September 21 2020; Peer review completed: October 31, 2020;

Revised version received and accepted: December 16, 2020; Published: December 21, 2020.

DOI: 10.15376/biores.16.1.1207-1229 